Sādhanā Vol. 36, Part 1, February 2011, pp. 1-15. @ Indian Academy of Sciences

\title{
A calculation method of cracking moment for the high strength concrete beams under pure torsion
}

\author{
METIN HUSEM*, ERTEKIN OZTEKIN and SELIM PUL \\ Department of Civil Engineering, Karadeniz Technical University, Trabzon, \\ 61080, Turkey \\ e-mail: mhusem@ktu.edu.tr
}

MS received 27 August 2009; revised 23 June 2010; accepted 24 July 2010

\begin{abstract}
In this study, a method is given to calculate cracking moments of high strength reinforced concrete beams under the effect of pure torsion. To determine the method, both elastic and plastic theories were used. In this method, dimensions of beam cross-section were considered besides stirrup and longitudinal reinforcements. Two plain high strength concrete (without reinforcement) and eight high strength reinforced concrete beams which have two different cross-sections $(150 \times 250 \mathrm{~mm}$ and $150 \times 300 \mathrm{~mm}$ ) were produced to examine the validity of the proposed method. The predictions of the proposed approach for the calculation of the cracking moment of beams under pure torsion were compared with the experimental and the analytical results of previous studies. From these comparisons it is concluded that the predictions of the proposed equations for the cracking moment of plain and reinforced high strength concrete beams under pure torsion are closer to the experimental data compared to the analytical results of previous theories.
\end{abstract}

Keywords. High strength concrete beam; pure torsion; torsional cracking; torsional moment; reinforced concrete; cracking moment.

\section{Introduction}

Although high strength concrete is commonly used, its properties are not known as much as the properties of ordinary concrete in design of reinforced sections. Torsion effect may be important especially in non-symmetrical reinforced concrete structural members. But, generally these effects are less than the other sectional effects. So they are usually neglected in calculations. Practically, torsion calculations must be made for stairs, bridges, corner columns, edge beams, box girders, etc. in which torsion is the primary effect (Ersoy 1986; Ersoy 1975; Larrad \& Mailer 1991; Wilby 1991). To determine torsion moment in reinforced concrete members, lots

*For correspondence 
of parameters were effective. For this reason, to calculate exact torsion moment in reinforced members is quite difficult (Collins \& Mitchell 1980; Nilson 1985; Swamy 1985).

There are a lot of suggestions and formulae to calculate the torsion moment and stress for plain concrete and reinforced concrete members in the literature (Hsu 1984; Kirk \& Lash 1971; Mitchell 1974; Kozonis 1977; Wang \& Hsu 1997; Koutchoukali \& Belarbi 1997; Onsongo 1978; Bakhsh et al 1990; Rasmussen \& Baker 1995; Karayannis \& Chalioris 2000; Fang \& Shiau 2004; Chalioris 2006). The theoretical approaches for the prediction of the torsional moment at cracking of plain and reinforced concrete members are (i) the elastic theory (Timoshenko \& Goodier 1969; Popov 1990), (ii) the plastic theory (Nilson 1985; Popov 1990), (iii) the skew bending theory (Hsu 1984) and (iv) a smeared cracked model (Karayannis \& Chalioris 2000) that properly modifies the classical Saint Venant's theory utilizing constitutive relations of normal stress and crack width for the tensional behaviour of concrete and has been proposed by Karayannis (2000). Another method is spaces truss theory to calculate the torsion moment capacity (ACI318 1989, 1999; McMullen \& Rangan 1978). Space truss models assume that a reinforced concrete member subjected to pure torsion is cracked and after cracking the diagonal cracks separate concrete into a series of concrete struts. This way, the external torsional moment is resisted by compression diagonals consisting of the concrete between crack that spiral around the beam (concrete struts) and by tensional elements consisting of the steel reinforcement (longitudinal bars and stirrups) as a space truss. Thus, although applications of this theory to reinforced concrete beams under torsion exhibit very reliable results for the prediction of the post-cracking behaviour and the ultimate torque, the predictions of the elastic stiffness and cracking capacity of analytical torque versus twist curves lies considerably below the test curves in all the examined cases in the literature (Hsu 1984; Fang \& Shiau 2004; Chalioris 2006).

A new expression is proposed to calculate cracking moment in high strength plain concrete and reinforced concrete under the effect of pure torsion moment. To determine this expression for plain concrete and reinforced concrete both plastic and elastic theories were used. All beams of the experimental program were tested under the action of pure torsion moment. Obtained results were compared with the predictions of the proposed method of this study and with the analytical results derived from the expressions proposed in previous studies of other researches and from the equations of ACI318 (1999) and TS500 (2000) codes.

\section{Theoretical study}

In this study, it is assumed that angles between axes with failure lines on faces of a high strength plain concrete beam are approximately $45^{\circ}$. These failure lines at around three faces of the beams are perpendicular to the diagonally tension stresses. The fourth one is compression line and connects to the tension lines that are on the top and bottom faces of the beams. Cracking angles are approximately $45^{\circ}$ and therefore lateral and longitudinal stresses can be calculated as $\sigma_{x}=\sigma_{y}=\sigma \cos 45^{\circ}$.

The longitudinal and lateral strains of high strength plain beams under pure torsion are calculated by eq. (1) depending on concrete strength up to failure (Oztekin et al 2003).

$$
\varepsilon_{x, y}=\varepsilon_{c}=\frac{0.00014 f_{c k}}{\left(f_{c k}+40\right)}\left(60 \mathrm{MPa} \leq f_{c k} \leq 94 \mathrm{MPa}\right)
$$

According to the plastic theory, there are four stress regions in a rectangular section (figure 1). Shear stresses in these regions work to twist the rectangular section around the A-B 


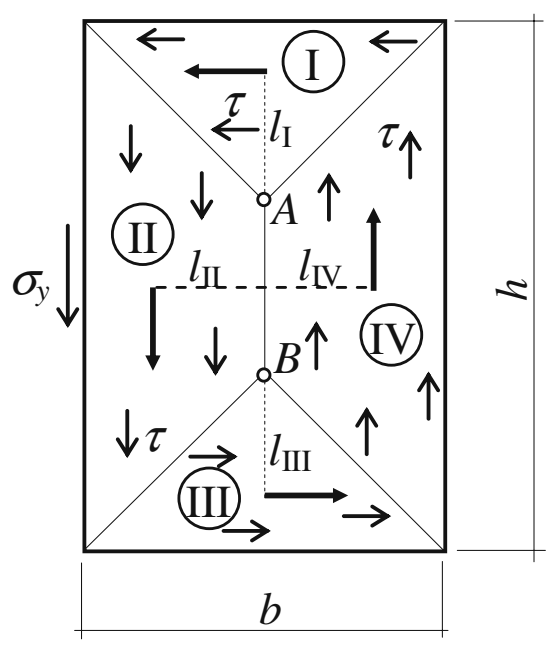

Figure 1. Stress distribution in a rectangular section according to plasticity theory (Nilson 1985; Popov 1990).

line. According to this assumption, eq. (2) can calculate torsional moment $\left(T_{C}\right)$ for rectangular plain concrete sections.

$$
T_{C}=A_{I} \tau l_{I}+A_{I I} \tau l_{I I}+A_{I I I} \tau l_{I I I}+A_{I V} \tau l_{I V}
$$

where, $A_{i}$ is area of region $i, l_{i}$ is the shortest length between total stress point and A-B line and $\tau$ is shear stress. If eq. (2) is written with sectional dimensions, then eq. (3) is obtained.

$$
T_{C}=\frac{b^{3}+3 h b^{2}}{12} \tau \text {. }
$$

Another assumption in this study is that shear stresses in a section are equal to lateral tensile stresses. To calculate concrete stress in a cross section of high strength concrete beams, failure strain is calculated using modified Hognestad model (Ersoy 1986; ACI318 1989; Eurocode-2 1999). According to this model, stresses can be calculated with eq. (4).

$$
\tau=\sigma_{y}=0.85 f_{c k}\left(k \frac{\varepsilon_{c}}{\varepsilon_{c o}}-(k-1)\left(\frac{\varepsilon_{c}}{\varepsilon_{c o}}\right)^{2}\right),
$$

where;

$$
\begin{aligned}
& k=2-\left(\frac{f_{c k}-40}{70}\right) \text { for } 42 \mathrm{MPa} \leq f_{c k} \leq 110 \mathrm{MPa} \text { and } k=1.1 \text { for } f_{c k}>110 \mathrm{MPa} \\
& \varepsilon_{c o}=\left[2.2+0.015\left(f_{c k}-40\right)\right] 10^{-3} .
\end{aligned}
$$

To calculate concrete stress in a cross section of high strength concrete beams, failure strain calculated using eq. (1). These equations are valid up to failure strains that are calculated by eq. (1) for high strength concrete sections under pure torsion.

In reinforced concrete sections both of the reinforcements and concrete resist to the shear stresses together. The shear stresses in the longitudinal reinforcements in a rectangular section are shown in figure 2 . 


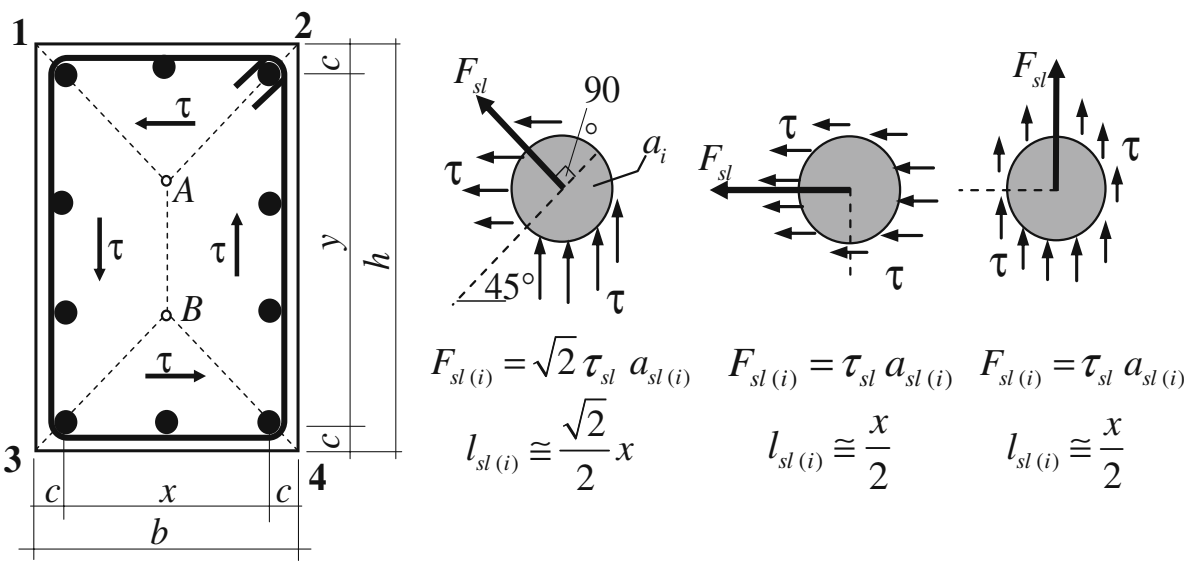

Figure 2. Shear stress and its directions on the longitudinal reinforcements.

It is assumed that more shear stresses occur on longitudinal reinforcements stated on the 1-A, 2-A, 3-B, and 4-B lines than the other longitudinal reinforcements. In this study, torsion carried by longitudinal reinforcement was calculated by eq. (6).

$$
T_{s l}=\sum_{i=1}^{n} F_{s l(i)} l_{s l(i)},
$$

where $F_{s l(i)}$ and $l_{s l(i)}$ are shear force at the $i$. longitudinal reinforcement and the shortest length between $F_{s l(i)}$ and A-B line, respectively. They can be calculated by eqs. (7) and (8) for the longitudinal reinforcements which are not stated on the lines 1-A, 2-A, 3-B and 4-B.

$$
\begin{gathered}
F_{s l(i)}=\tau_{s l} a_{s l(i)} . \\
l_{s l(i)} \cong \frac{x}{2} .
\end{gathered}
$$

If longitudinal reinforcements are stated on the 1-A, 2-A, 3-B and 4-B lines then, $F_{S l(i)}$ and $l_{s l(i)}$ can be calculated by eqs. (9) and (10).

$$
\begin{gathered}
F_{s l(i)}=\sqrt{2} \cdot \tau_{s l} a_{s l(i)} . \\
l_{s l(i)} \cong \frac{\sqrt{2}}{2} x,
\end{gathered}
$$

where; $a_{s l(i)}$ is area of the $i$. longitudinal reinforcement and c is concrete cover thickness.

In this study it is also assumed that strains of the reinforcement and concrete are equal $\left(\varepsilon_{s}=\varepsilon_{c}\right)$ up to cracking. According to Hooke's law, stress in a section can be calculated with $\sigma=E \varepsilon$. At this time, shear stress in the longitudinal reinforcement can be calculated with eq. (11).

$$
\tau_{s l}=E_{s l} \varepsilon .
$$

It is also assumed that stirrups, used for reinforcement, increase torsional capacity of high strength concrete beams. All these stirrups are assumed as a thin-walled tube in a beam. Shear 


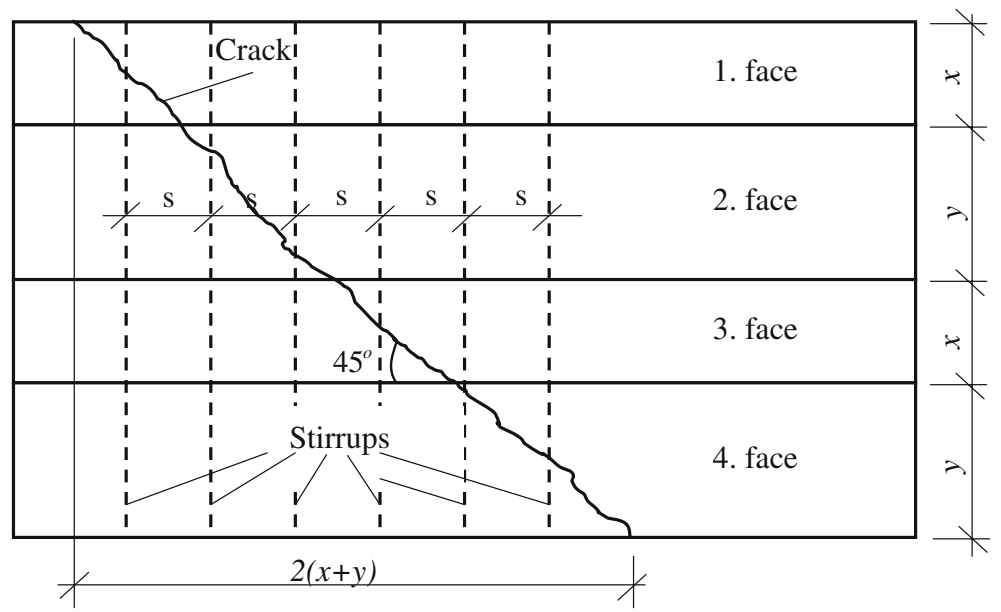

Figure 3. Intersections between torsion cracks with stirrups.

stress on stirrups works to twin reinforced section around A-B line and stirrups resist to this shear stress. Like longitudinal reinforcement, behaviour of stirrups is elastic up to the cracking. Torsion that is carried by transverse reinforcement can be calculated with eq. (12).

$$
T_{s t}=F_{s t} l_{s t} .
$$

In eq. (12), $F_{s t}=\tau_{s t} A_{s t}$ is total shear force on the thin-walled tube section and $l_{s t} \cong \frac{x}{2}$ is the length between A-B line with thin-walled tube, where $\tau_{s t}=E_{s t} \varepsilon, A_{s t}=\frac{V_{s t}}{s}=\frac{2(x+y) a_{s t}}{s}$ area of thin-walled tube section, $V_{s t}$ is volume of stirrups, $a_{s t}$ is area of a stirrup section and $s$ is distance between stirrups.

If eq. (12) is rearranged according to these, eq. (13) can be obtained as

$$
T_{s t}=\frac{\varepsilon E_{s t} x(x+y)}{s} a_{s t} .
$$

The number of intersection between torsion cracks and stirrups (figure 3) can be calculated as;

$$
\begin{aligned}
n & =2(x+y) / s \\
T_{s t} & =n l_{s t} E_{s t} \varepsilon a_{s t} .
\end{aligned}
$$

Finally, total torsional moment carried with whole high strength reinforced concrete section up to cracking is calculated with eq. (15).

$$
T=T_{c}+\sum T_{s l}+T_{s t}
$$

In the calculations elasticity modulus of reinforcements are taken as $E_{s l}=E_{s t}=$ $2.1 \times 10^{5} \mathrm{MPa}$.

\section{Experimental study}

In this study, two plain concrete (without reinforcement) and eight reinforced concrete beams were produced. The high strength beams were produced in $150 \times 250 \mathrm{~mm}$ and $150 \times 300 \mathrm{~mm}$ 
Table 1. Section properties and reinforcement details of test beams.

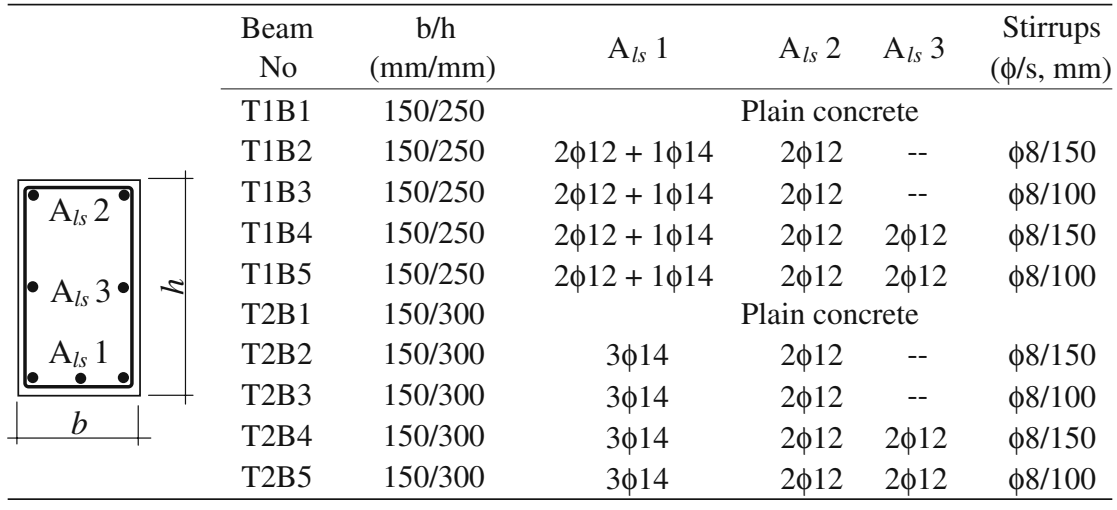

cross section and $1400 \mathrm{~mm}$ length. Concrete cover thickness of these beams was $20 \mathrm{~mm}$. Section properties and reinforcement details of these high strength concrete beams are shown in table 1 .

Crushed limestone aggregate was used in the production of high strength concrete. The maximum aggregate size was $16 \mathrm{~mm}$. Some the physical properties and mix proportions of aggregates are given in table 2 .

In the production of the concretes, the cement used was rapid hardening ordinary portland cement (CEM-I $42.5 \mathrm{R}$ ). In addition to cement and aggregate, silica fume containing $81 \% \mathrm{SiO}_{2}$ and high range water-reducing admixtures (ASTM C-494 F type super plasticizer) were used in the production of high strength concrete. In the mixture proportioning of high strength concrete, water to cement ratio of 0.3 was used. The mix design of high strength concrete is given in table 3.

High strength concrete beams were produced with 12 standard cylindrical specimens ( $150 \mathrm{~mm}$ diameter and $300 \mathrm{~mm}$ height). The specimens were 28-day-old at the time of the experiments. Mechanical properties of reinforcements were determined to the tensile tests on the reinforcements being used in test beams. Some mechanical properties of the high strength concrete and reinforcement steel of the beams are given in table 4.

To make pure torsion tests on the high strength plain concrete and reinforced concrete beams, a test set-up was designed given in figure 4. Test beams were placed between fixed and rotary supports. Rotary support was placed on the reaction wall. A tapered roller bearing was placed to

Table 2. Some physical properties and mix proportions of the aggregates.

\begin{tabular}{lcccccc}
\hline Aggregate size & $\begin{array}{c}\text { Bulk } \\
\text { density } \\
\left(\mathrm{kg} / \mathrm{m}^{3}\right)\end{array}$ & $\begin{array}{c}\text { Water } \\
\text { absorption } \\
(\%)\end{array}$ & $\begin{array}{c}\phi 50 \mathrm{~mm} \\
\text { core } \\
\text { strength } \\
(\mathrm{MPa})\end{array}$ & \multicolumn{2}{c}{$\begin{array}{c}\text { Mix proportions in concrete } \\
(\%)\end{array}$} \\
\cline { 5 - 7 } & & & & $\begin{array}{c}\text { Fine } \\
(0-4 \mathrm{~mm})\end{array}$ & $\begin{array}{c}\text { Medium } \\
(4-8 \mathrm{~mm})\end{array}$ & $\begin{array}{c}\text { Coarse } \\
(8-16 \mathrm{~mm})\end{array}$ \\
\hline Fine $(\leq 4 \mathrm{~mm})$ & 2671 & 0.43 & 76 & 50 & 25 & 30 \\
Coarse $(>4 \mathrm{~mm})$ & 2706 & 0.55 & & & & \\
\hline
\end{tabular}


Table 3. Mix design of high strength concrete.

\begin{tabular}{ccccccc}
\hline W/C & $\begin{array}{c}\text { Cement } \\
\left(\mathrm{kg} / \mathrm{m}^{3}\right)\end{array}$ & $\begin{array}{c}\text { Water } \\
\left(\mathrm{kg} / \mathrm{m}^{3}\right)\end{array}$ & $\begin{array}{c}\text { Total } \\
\text { aggregate } \\
\left(\mathrm{kg} / \mathrm{m}^{3}\right)\end{array}$ & $\begin{array}{c}\text { Absorbed } \\
\text { water } \\
\left(\mathrm{kg} / \mathrm{m}^{3}\right)\end{array}$ & $\begin{array}{c}\text { Silica } \\
\text { fume } \\
\left(\mathrm{kg} / \mathrm{m}^{3}\right)\end{array}$ & $\begin{array}{c}\text { Super } \\
\text { plasticizer } \\
\left(\mathrm{kg} / \mathrm{m}^{3}\right)\end{array}$ \\
\hline 0.3 & 500 & 150 & 1716 & 16.08 & 50 & 11 \\
\hline
\end{tabular}

fixed system on the reaction wall and roller bearing's ring was located in the end face of concrete beams as in figure $4 \mathrm{~b}$. These rings were placed to each beam mould before concrete casting. This roller bearing was used to make beam to rotate easily its longitudinal axis under pure torsion. Torsion was given to the beam using a moment arm that is placed in the end of the beam closed to the simple support. Fixed support was connected to the strong floor of the reaction wall. A load-cell and a manual controlled hydraulic cylinder that are located under the moment arm were used in these experiments.

In the pure torsion tests, two strain-gauges having $120 \mathrm{~mm}$ measurement length were placed into middle of the left and right sides of the beams in order to measure longitudinal strains. And also torsional cracking and ultimate torsional moments by twisting beams were obtained from the pure torsion experiments.

\section{Results and discussions}

The standard cylinders $(150 \times 300 \mathrm{~mm})$ were taken from the concrete produced for test beams and compressive strength was determined. The characteristic compressive strength $\left(f_{c k}\right)$ of these concretes was $66 \mathrm{MPa}$. Therefore in the production of test beams high strength concrete was used.

Failure types of the high strength plain concrete beams that are tested under pure torsion were very brittle like plain beams produced with ordinary concrete. Failure is spirally formed around the beams. Failure occurs suddenly when the maximum principal tensile stress exceeds the tensile strength of high strength concrete. Only one failure line was occurred on these beams. But, a lot of tension cracks were occurred on the reinforced beams. And the same crack form was also observed in the high strength reinforced beams. Typical crack patterns of reinforced concrete high strength beams after pure torsion tests were given in figure 5 .

Observations show that the tension crack forms at about $45^{\circ}$, which are perpendicular to the diagonal tension stresses as shown in figure 6. Longitudinal strains obtained from pure torsion

Table 4. Some mechanical properties of concrete and reinforcement steel.

\begin{tabular}{llllll}
\hline \multicolumn{2}{l}{ High strength concrete } & \multicolumn{4}{l}{ Reinforcement steel } \\
\hline $\begin{array}{l}\text { Characteristic } \\
\text { compressive } \\
\text { strength }\end{array}$ & $\begin{array}{l}\text { Standard } \\
\text { deviation }\end{array}$ & $\begin{array}{l}\text { Initial modulus } \\
\text { of elasticity }\end{array}$ & $\begin{array}{l}\text { Ultimate } \\
\text { strain }\end{array}$ & $\begin{array}{l}\text { Characteristic } \\
\text { yield strength }\end{array}$ & $\begin{array}{l}\text { Standard } \\
\text { deviation }\end{array}$ \\
\hline $\begin{array}{l}f_{c k}(\mathrm{MPa}) \\
66\end{array}$ & $(\mathrm{MPa})$ & $E_{c}(\mathrm{MPa})$ & $10^{3} \varepsilon_{c u}$ & $f_{y k}(\mathrm{MPa})$ & $(\mathrm{MPa})$ \\
\hline
\end{tabular}




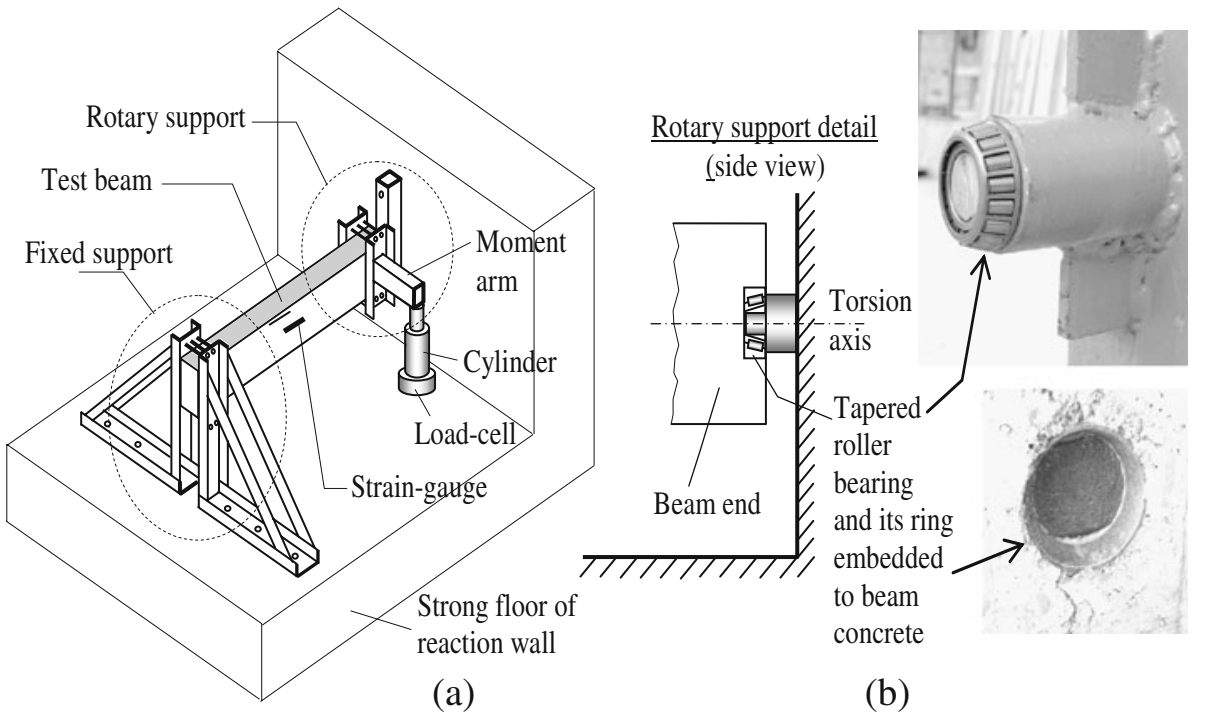

Figure 4. Pure torsion test set-up (a) and rotary support detail (b).

tests were measured about $1 \times 10^{-4}$ for the high strength concrete plain beams at failure. This result can be seen in figure 7 for T1B1 and T2B1 series high strength concrete beams.

Expressions proposed in this study to determine cracking moment under the effect of pure torsion in high strength plain concrete and reinforced concrete cross sections were given in table 5 together with the expressions proposed by some researchers and codes.

The results obtained from the tests of this study were given in table 6 to be compared with the results obtained from the expressions given in table 5 .

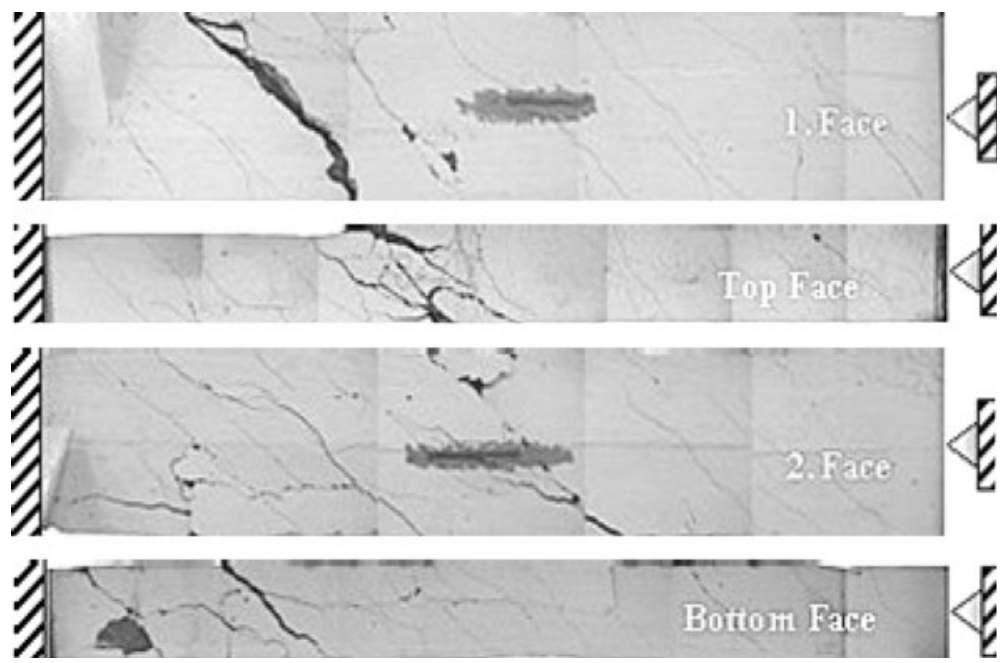

Figure 5. Typical crack patterns of reinforced beam faces after tests. 


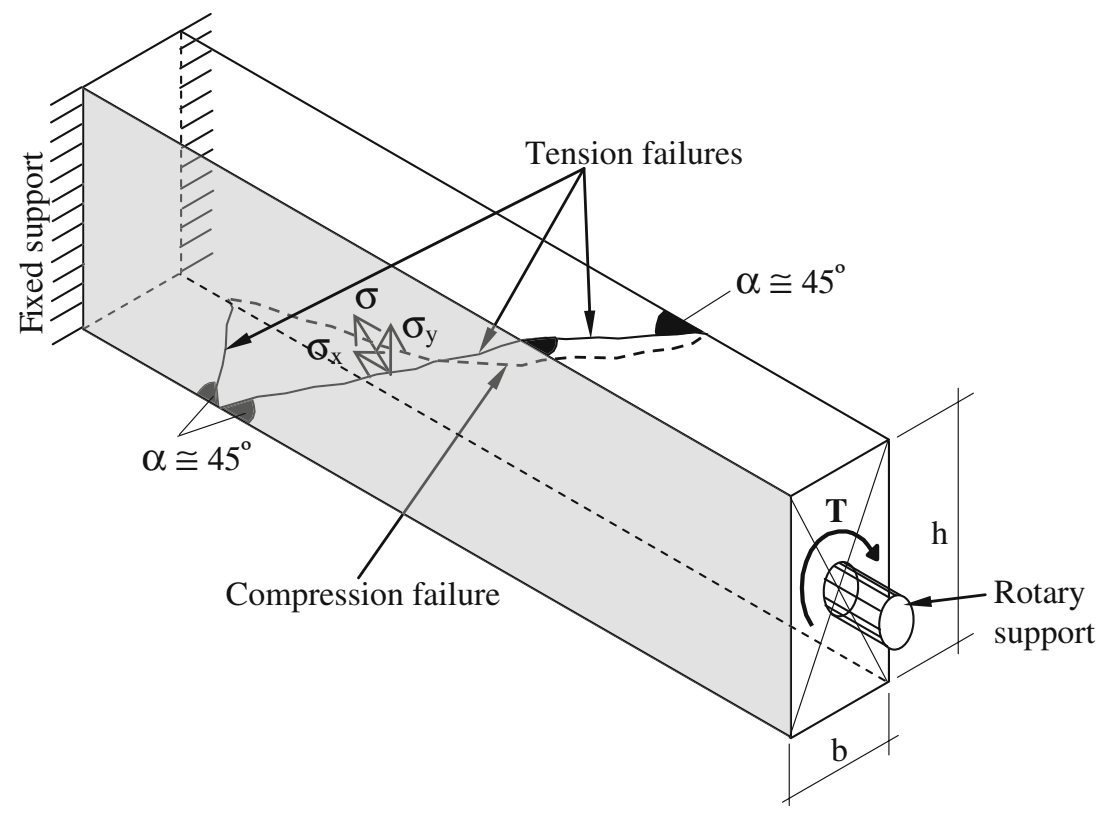

Figure 6. Tension crack forms on the high strength concrete plain beams.

As seen in the table, cracking moments calculated by the help of proposed expression in this study is close to the experimental results.

To determine the validity of proposed expressions, results obtained from the expression proposed in this study were compared with the results obtained from test results done by other
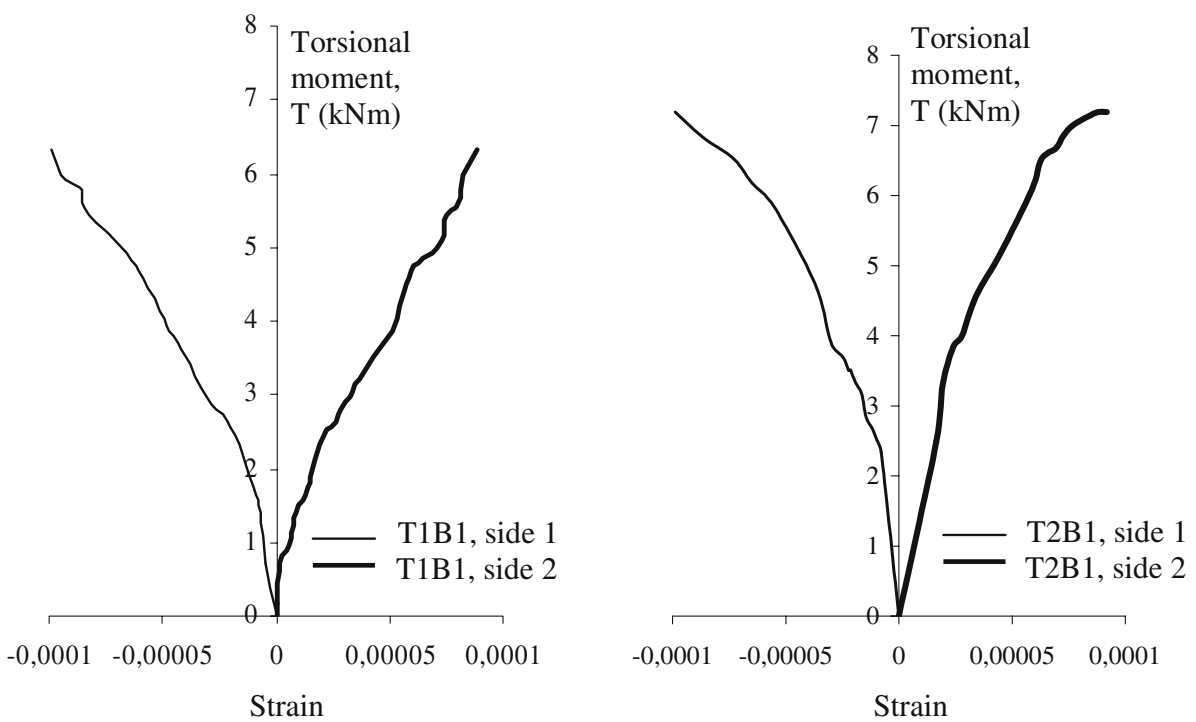

Figure 7. Variation of longitudinal strains with torsional moment at middle of the plain concrete beam's sides. 
Table 5. Some proposed methods for prediction of cracking moment under pure torsion.

Proposed

Equation

Elastic theory (Timoshenko \& Goodier 1969; Popov 1990)

$$
\begin{aligned}
T & =\alpha\left(x^{2} y\right)\left(6 \sqrt{f_{c^{\prime}}}\right) \\
T & =\left(0.5-\frac{x}{6 y}\right)\left(x^{2} y\right)\left(6 \sqrt{f_{c^{\prime}}}\right) \\
T & =4 \sqrt{f_{c}^{\prime}} \frac{A_{c}^{2}}{P_{c}} \\
T & =(1.35)\left(0.35 \sqrt{f_{c}^{\prime}}\right)\left(\frac{b^{2} h}{3}\right) \\
T & =\left(\frac{x^{2} y}{3}\right)(0.85)\left(21\left(1+\frac{10}{x^{2}}\right)\left(\sqrt[3]{f_{c}^{\prime}}\right)\right) \\
T & =\left(\frac{x^{2} y}{3}\right)(0.85)\left(7.5 \sqrt{f_{c}^{\prime}}\right) \\
T & =6\left(x^{2}+10\right) y\left(\sqrt[3]{f_{c}^{\prime}}\right) \\
T_{c} & =\tau \frac{b^{3}+3 h b^{2}}{12}
\end{aligned}
$$

Plastic theory (Nilson 1985; Popov 1990)

TS 5002000 (Turkish Standards Institution)

Skew B. Theory-1 (Hsu 1984; Hsu \& Mo 1985)

Skew B. Theory-2 (Hsu 1984; Hsu \& Mo 1985)

Skew B. Theory-3 (Hsu 1984; Hsu \& Mo 1985)

This study (for plain sections)

$\tau=0.85 f_{c k}\left(k \frac{\varepsilon_{c}}{\varepsilon_{c o}}-(k-1)\left(\frac{\varepsilon_{c}}{\varepsilon_{c o}}\right)^{2}\right)$

$T=T_{c}+T_{s l}+T_{s t}$

$T_{C}=\frac{b^{3}+3 h b^{2}}{12} \tau$

This study (for reinforced sections)

$$
\begin{aligned}
T_{s l} & =\sum_{i=1}^{n} F_{s l(i)} l_{s l(i)} \\
T_{s t} & =\frac{\varepsilon E_{s t} x(x+y)}{s} a_{s t}
\end{aligned}
$$

researchers (Hsu 1984; Hsu \& Mo 1985; Koutchoukali \& Belarbi 1997, 2001; Zhang 2002; Rasmussen \& Baker 1995; Mohammadizadeh \& Fadaee 2009; Chiu et al 2007; Fang \& Shiau 2004). Beside the ratio of results obtained from the expressions proposed in this and other studies of researchers tests were given in table 7 .

As seen in table 7 for plain and reinforced high strength concrete cross section, cracking moments obtained from the expression proposed in this study were closer to the test results done by other researchers in an average sense. Cracking moments obtained from the expression proposed in ACI 318 was much smaller than both the results of experiment in this study and the results of experiments done by other researchers. The expression by TS 500 standard produced bigger results than experimental results with the biggest standard deviation. Skew bending-1 theory has smaller standard deviation (0.178) than the theory proposed in this study $(0.184)$. But the theory proposed in this study produced closer results in an average sense. Although the expressions proposed by elastic theory, plastic theory, skew bending- 2 theory and skew bending3 theory have smaller standard deviations, their averages are not closer to the experimental results than Skew bending-1 theory and proposed theory in this study. 


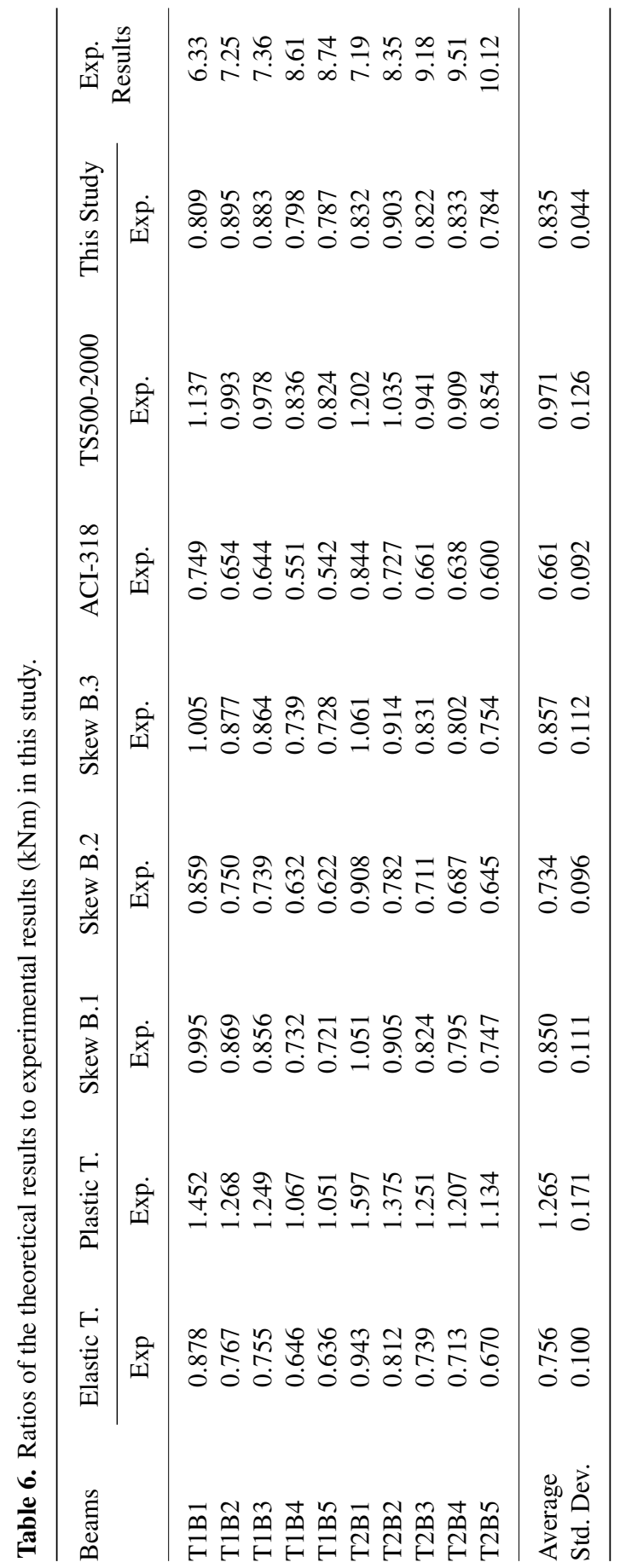




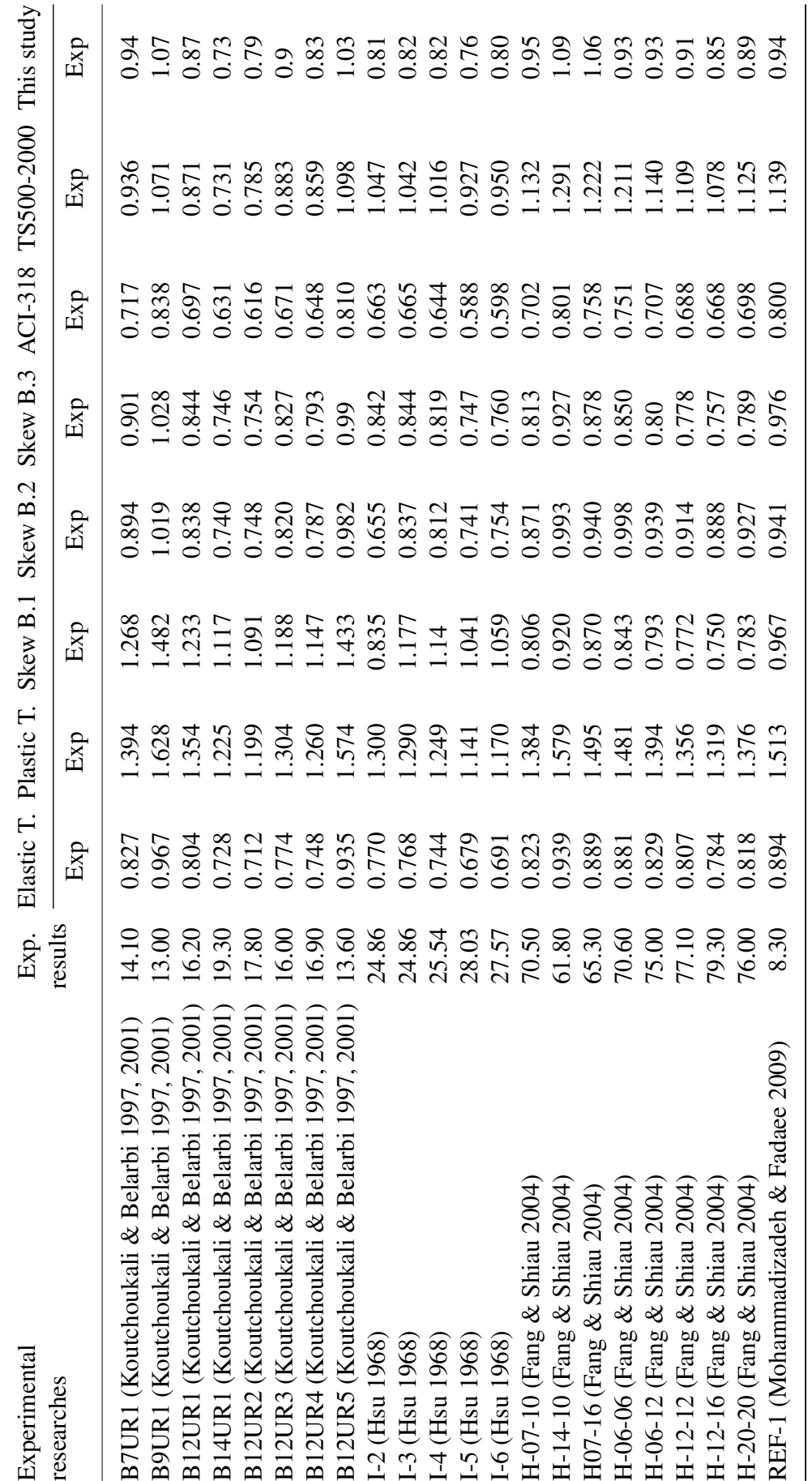




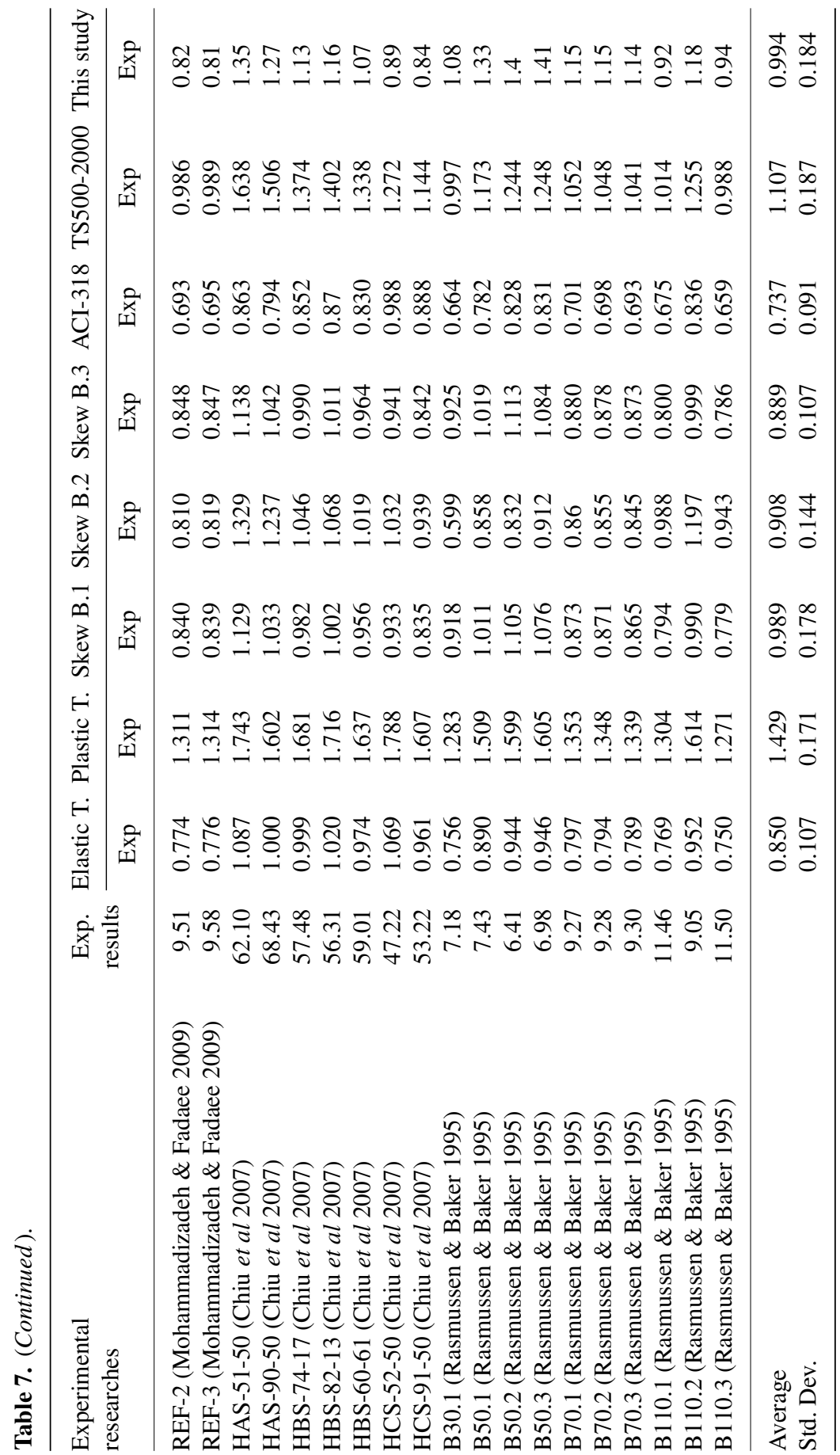




\section{Conclusions}

From this study, the following conclusions can be drawn;

(i) The elastic, the plastic and the skew bending theories, along with the current expressions of ACI318 code used to obtain the torsional capacity of concrete sections, can not predict accurately the cracking torsional capacity for plain and reinforced high strength concrete members.

(ii) Experimental studies show that reinforcement increases cracking capacity of high strength concrete beams under pure torsion.

(iii) New method has been proposed to obtain cracking capacity of high strength plain and reinforced concrete sections under pure torsion.

(iv) Validity of the new method is proved by using experimental results of previous research works.

\section{References}

ACI 318-89 1989 Building code requirements for reinforced concrete. American Concrete Institute, Detroit

ACI 318-99 1999 Building code requirements for reinforced concrete. American Concrete Institute, Detroit

Bakhsh A H, Wafa F F and Akhtaruzzaman A A 1990 Torsional behaviour of plain high-strength concrete beams. ACI Struct. J. 87: 583-588

Chalioris C E 2006 Experimantal Study of the torsion of reinforced concrete members. Struct. Eng. Mech. 23: 713-737

Chiu H-J, Fang I-K, Young W-T and Shiau J-K 2007 Behaviour of reinforced concrete beams with minimum torsional reinforcement. Eng. Struct. 29: 2193-2205

Collins M P and Mitchell D 1980 Shear and torsion design of prestressed and non-prestressed concrete beams. PCI Journal 25: 32-100

Ersoy U 1975 Torsion in reinforced concrete. Guven Kitabevi, Ankara

Ersoy U 1986 Reinforced concrete. METU, Ankara

Eurocode-2 1999 Design of concrete structures. European Committee for Standardization, Brussels

Fang I K and Shiau J K 2004 Torsion behaviour of normal and high strength concrete beams. ACI Struct. J. 101: 304-312

Hsu T T C 1968 Torsion of structural concrete behavior of reinforced concrete rectangular members. Torsion Struct. Concr. SP-18 ACI 261-306

Hsu T T C 1984 Torsion of reinforced concrete. Van Nostrand Reinhold Company

Hsu T T C and Mo Y L 1985 Softening of concrete in torsional members-theory and tests. ACI Journal 82: $290-303$

Karayannis C G 2000 Smeared crack analysis for plain concrete in torsion. J. Struct. Eng. 126: 638-645

Karayannis C G and Chalioris C E 2000 Experimental validation of smeared analysis for plain concrete in torsion. J. Struct. Eng. 126: 646-653

Kirk D W and Lash S D 1971 T-beams subjected to combined bending and torsion. ACI Journal 68: $150-159$

Koutchoukali N and Belarbi A 1997 Effect of concrete strength on the behavior of RC beams subjected to pure torsion. High Strength Concrete First International Conference, (Hawaii), 38-51

Koutchoukali N and Belarbi A 2001 Torsion of high-strength reinforced concrete beams and minimum reinforced requirement. ACI Struct. J. 98: 462-469

Kozonis D 1997 Strength evaluation and retrofit of reinforced concrete beams subjected to pure torsion. MSc Thesis, Rice University, Texas 
Larrad F and Mailer Y 1991 High strength concrete. Second National Concrete Conference, (Istanbul), 76-113

McMullen A E and Rangan B V 1978 Pure torsion in rectangular sections - A re-examination. ACI Journal 75: 511-519

Mitchell D 1974 The behaviour of structural concrete beams in pure torsion. PhD. Thesis, University of Toronto

Mohammadizadeh M R and Fadaee M J 2009 Torsional behaviour of high-strength concrete beams strengthened using CFRP sheets; An experimental and analytical study. Transaction A: Civil Eng. V 16: (4): 321-330, Sharif University of Technology, August

Nilson A H 1985 Design implications of current research on high strength concrete. High Strength Concrete (ACI SP-87), Detroit, 85-118

Onsongo M W 1978 The diagonal compression field theory for reinforced concrete beams subjected to combined torsion, flexure, and axial load. PhD. Thesis, University of Toronto

Oztekin E, Pul S and Husem M 2003 Determination of rectangular stress block parameters of high strength concrete. Eng. Struct. 25: 371-376

Popov E P 1990 Engineering mechanics of solids. New Jersey: Prentice-Hall

Rasmussen L J and Baker G 1995 Torsion in reinforced normal and high-strength concrete beams-Part 1: Experimental test series. ACI Struct. J. 92: 56-62

Timoshenko S and Goodier J N 1969 The theory of elasticity. Istanbul, Ari Kitabevi

TS 5002000 Requirements for design and construction of reinforced concrete structures. Ankara: Turkish Standards Institution

Swamy R N 1985 High strength concrete-material properties and structural behaviour. High Strength Concrete (ACI SP-87), Detroit, 119-146

Wang W and Hsu T T C 1997 Limit analysis of reinforced concrete beams subjected to pure torsion. J. Struct. Eng. 123: 86-94

Wilby C B 1991 Concrete materials and structures. Revised Edition, Cambridge University

Zhang Y 2002 Torsion in high strength concrete rectangular beams. MSc. Thesis, University of Nevada, Reno 